\title{
Twelve years biomass response in aspen com- munities following fire
}

\author{
DALE L. BARTOS, JAMES K. BROWN, AND GORDON D. BOOTH
}

\begin{abstract}
The authors are, respectively, research ecologist, superivory research forester, and supervisory mathematical statistician, USDA Forest Service, Intermountain Research Station, Ogden, Utah. Bartos is located at the Forestry Sciences Laboratory, Logan, Utah; Brown is located at the Fire Sciences Laboratory, Missoula, Mont.; and Booth is located at Station Headquarters in Ogden, Utah.
\end{abstract}

\begin{abstract}
Vegetation responses to prescribed fire over a 12-year period are reported for several deteriorating aspen clones in northwestern Wyoming. This study extends earlier work by Bartos and Mueggler (1981) on a prescribed fire intended to regenerate these aspen clones. After 3 years, numbers of suckers were close to pre-burn levels ranging between 10,000 to 20,000 suckers/ha. After 12 years, 1,500 to 2,400 suckers/ha remained at a meager height averaging approximately $0.5 \mathrm{~m}$. The demise of this aspen was attributed to heavy ungulate use, primarily elk. Total undergrowth production increased substantially by the second postfire year and declined slowly after that. Biomass values of $2,130 \mathrm{~kg} / \mathrm{ha}$ (low burn severity), $2,140 \mathrm{~kg} / \mathrm{ha}$ (moderate burn severity), and $2,190 \mathrm{~kg} / \mathrm{ha}$ (high burn severity) were recorded after 12 years. This exceeds preburn production by 23 to $46 \%$. Forbs made up approximately $75 \%$ of the undergrowth production after 12 years, which was dominated by a dramatic postburn shift to fireweed (Epilobium angustifolium $\mathrm{L}$.). The remaining production was comprised of approximately $20 \%$ grasses and $5 \%$ shrubs. Most of the fluctuation in species composition occurred on the high severity burn sites.
\end{abstract}

Key Words: Populus tremuloides, elk, aspen reproduction, fire effects

Aspen ( Populus tremuloides Michx.) dominated forests are recognized for their multiple values, including forage use by livestock and wildlife ungulates, water, recreational opportunities, and panoramic vistas (DeByle and Winokur 1985). In the absence of disturbance, however, some of these values are diminished. The role of fire in perpetuating aspen forests has long been recognized (Baker 1925). Without periodic fire disturbance, many aspen stands are replaced by conifers or shrubs and herbaceous vegetatation (Jones and DeByle 1985). Kay (1990) discussed climax aspen stands in the Greater Yellowstone Ecosystem and speculated these stands would regenerate if ungulate browsing was lower.

Most aspen stands in the West are mature or overmature (Mueggler 1989). In the Intermountain West many stands are considered decadent. Only a small percentage of the stands are less than 60 years of age. A major disturbance (e.g., burning or clearcutting) that kills the standing aspen is necessary to regenerate stands that face rapid takeover by conifers or are in deteriorating condition with poor sucker reproduction.

Prescribed fire can be used to rejuvenate aspen. Suckering and undergrowth vegetation generally increase, sometimes substantially, within the first 2 or 3 years following prescribed fire (Bartos and Mueggler 1981, Brown and DeByle 1989). Less is known about longer term response of vegetation. Successful vegetative response following prescribed fire can be adversely affected by livestock and

Manuscript accepted 28 May 1993. wild ungulate grazing (Bartos and Mueggler 1979, Bartos 1979, Mueggler and Bartos 1977).

It has been postulated that western aspen stands that are burned can regenerate themselves despite heavy elk use (Houston 1982, Despain et al. 1986, Greull and Loope 1974). In 1974, a study was initiated on the Bridger-Teton National Forest to evaluate the effects of prescribed burning on decadent aspen stands (Bartos and Mueggler 1981). The primary purpose of the prescribed fire was to produce more aspen suckers than the transitory elk (Cervus elaphus) could consume and thus perpetuate the aspen stands. The study sites were sampled in 1974-1977, 1980, and 1986 to evaluate vegetation response. This paper reports on the 6- and 12-year (1980) and 1986) postfire vegetation response related to severity of burning and relates this information to the earlier work by Bartos and Mueggler (1981).

\section{Methods}

Breakneck Ridge, the study site, is located approximately $48 \mathrm{~km}$ northeast of Jackson, Wyo. The site is at 2,400-m elevation and is near the upper end of the Gros Ventre river drainage. Prior to treatment, the 200-ha site consisted of aspen, conifer (mostly subalpine fir Abies lasiocarpa (Hook.) Nutt.), big sagebrush (Artemisia tridentata Nutt.), and grassland communities. A prescribed burn was carried out by the Bridger-Teton National Forest on 29 August 1974. Variable fuel quantities, fuel moistures, and wind speeds created different burn severities.

Permanent plots that were established prior to burning were sampled intermittently over a 12-year period $(1974,1975$, 1976, 1977,1980 , and 1986). The plots were located in 10 aspen clones (2-5 ha each) which were situated across the study site. Nine of the clones were within the burn area while the most southerly clone was protected from burning and served as a control. Within each clone, 4 permanent macroplots $(10 \times 10-\mathrm{m})$ were selectively located. All macroplots were sampled in 1974-1977 (Bartos and Mueggler 1981) and 1980. Weather and time constraints allowed us to sample only 36 of the 40 macroplots in 1986.

In 1980 and 1986, we repeated the earlier sampling procedures with some modifications to improve efficiency. Initially, sucker density was obtained by counting suckers on five 4- $\mathrm{m}^{2}$ permanent subplots located within each of the $\mathbf{4 0}$ macroplots. Aspen suckers declined precipitously after the first 4 years of the study, therefore, we were able to count suckers on the entire macroplot $\left(100 \mathrm{~m}^{2}\right)$. Aspen suckers were defined as any aspen stem less than $2 \mathrm{~m}$ in height and less than 5-cm diameter at breast height (dbh).

Vegetation production in 1974-1977 and 1980 was sampled with a double sampling procedure used to develop relationships between clipped vegetation and capacitance meter readings (Currie et al. 1973). A portion of the metered plots were clipped by species which 
allowed for the total herbage production to be separated into its component parts. In 1986, 20 microplots $(30 \times 60 \mathrm{~cm})$ were systematically distributed within each macroplot. These microplots, as well as all previous microplots, were clipped and bagged by species. All clipped material was dried at $70^{\circ} \mathrm{C}$ until it reached a constant weight (minimum of 48 hours). Vegetation production was then expressed on a dry weight basis. Clipping by species permitted us to express species composition as a percent of total production. Vegetation was sampled in late July and early August in all years to obtain peak production.

Mortality of mature aspen trees was not uniform across the site, a common result of fire in western aspen stands (Brown and DeByle 1989). Bartos and Mueggler (1981) assigned each of the macroplots to 1 of 4 burn intensity classes: unburned (control plots), light burn ( 1 to $20 \%$ of the litter and duff consumed and none or few mature aspen trees killed), moderate burn (21 to $80 \%$ of the litter and duff consumed and $<90 \%$ of the mature aspen trees killed), and heavy burn ( 81 to $100 \%$ of the litter and duff consumed and $>90 \%$ of the mature aspen trees were killed). The burn intensity classes are more properly referred to as burn severity (Ryan and Noste 1985). They will be described as low, moderate, and high burn severity. The 4 macroplots in the control treatment were without evidence of fire and were classified as unburned. Of the remaining 36 macroplots, 11 were classified as low severity, 13 were moderate severity, and 12 were high severity.

Statistical analysis of vegetation production and sucker numbers using a square root transformation) included an analysis of variance to determine if differences exist for main effects: (1) burn severity (control, low, moderate, high); (2) years $(1974,1975,1976$, 1977,1980 , and 1986); and (3) severity $\times$ year interaction. Because we are comparing all 3 burn severities against the control area, we chose the Dunnett (1955) statistic which was designed specifically for these types of comparisons.

\section{Results and Discussion}

\section{Suckers}

Sucker densities 6 years after fire ranged from 4,300 to 10,300 suckers / ha for the 3 burn severities, which was approximately the same as before fire (Table 1). Sucker densities 12 years after fire, for

\section{Table 1. Sucker density (number/ha) obtained for 4 burn severities and 6 sample years for the Breakneck Ridge site which was burned in 1974. ANOV procedures were run using a square root transformation of the data. Mean values are on top and standard errors of the mean (SEM) are shown below.}

\begin{tabular}{lcrrrrr}
\hline \hline $\begin{array}{l}\text { Burn } \\
\text { severity }\end{array}$ & 1974 & 1975 & 1976 & 1977 & 1980 & 1986 \\
\hline \multirow{3}{*}{ Control } & $8500^{1}$ & 18625 & 16750 & 18625 & 12250 & 5150 \\
& 3373 & 4023 & 3455 & 2585 & 3099 & 1981 \\
Low & 4000 & 7727 & 15727 & 8636 & 4318 & $1518^{*}$ \\
& 1452 & 2322 & 4093 & 2140 & 1995 & 686 \\
Moderate & 5962 & 18692 & 30692 & 20154 & 9654 & $1854^{*}$ \\
& 1535 & 5121 & 8528 & 5230 & 2876 & 721 \\
High & 8417 & $7333^{*}$ & 36458 & 21792 & 10292 & 2400 \\
& 1633 & 2831 & 7114 & 3889 & 2839 & 589 \\
\hline
\end{tabular}

'Burn severity means in various columns (years) followed by an * are significantly different ( $P<0.10$, Dunnett) from the control.

the 3 burn severities, ranged from 1,500 to 2,400 suckers/ ha, which was 29 to $38 \%$ less than preburn densities. The control area had 5,150 suckers/ha in 1986 compared to 8,500 suckers/ha that occurred prior to treatment. This represents a $39 \%$ reduction in sucker numbers on the control, which can be attributed to elk use because of the control site's close proximity to the burn.
Interaction of sucker density between burn severity and years was not detectable statistically, which indicates that pooling across years is possible. However, we chose to look at individual years as we felt it would be more appropriate to evaluate these data on a yearly basis. The 3 burn severities were compared to the control and we found no statistically significant difference $(P>0.10)$ for 1974-1980 except for 1975 where the high severity burn was statistically different from the control (Table 1). In 1986 both the low and moderate severity burns produced significantly fewer suckers than the control.

Sucker densities were within but at the lower range of 2,100 to 49,300 suckers/ ha reported for the 5 th and 6 th postburn years in other studies: Patton and Avant (1970) in Arizona, Brown and DeByle $(1987,1989)$ in southeastern Idaho and southwestern Wyoming, and Bartos et al. (1991) in the Gros Ventre drainage of Wyoming. As anticipated, there was an initial flush of suckers at Breakneck followed by a marked decline the year after peak densities were reached. In the other studies, peak densities occurred 1 or 2 years after fire followed by a decline over a 4 to 6 year period. The decline in density varied from gradual to rapid but appeared to level off after 4 to 6 years in most of the clones. The continual decline in sucker density at Breakneck to levels considerably below preburn densities was also observed on another prescribed fire (Brown and DeByle 1989). In that study, however, postburn biomass of suckers exceeded preburn biomass even though densities were less.

The lack of significant relationship between sucker density and burn severity was also reported by Brown and DeByle $(1987,1989)$. Knowledge of suckering (Schier et al. 1985) suggests that moderate severity fires should produce the greatest number of suckers because tree mortality removes apical dominance and root mortality is minimal. But demonstrating this on prescribed fires is difficult because other factors such as parent stand vigor, density of root systems, clonal characteristics, and competition with other vegetation can mask the effects of burn severity (Brown and DeByle 1987).

Growth rates of aspen suckers was reported by Bartos, et al. (1991) to have been between 0.02 and $0.22 \mathrm{~m}$ per year on burned aspen sites in western Wyoming. At Breakneck Ridge after 12 growing seasons, sucker heights averaged approximately $0.5 \mathrm{~m}$, which was similar to that reported earlier (Bartos and Mueggler 1981) and indicates repeated browsing. Cattle graze the area 3 out of 4 summers in a rest-rotation program and the area does not appear to be overly impacted as a result of this grazing. It was observed that cattle seldom used aspen suckers while in the area. Elk use is severe during the fall-winter-spring period because the study site is along an elk migration route. Decreased sucker production attributed to heavy ungulate use was observed on other aspen burn sites in the Greater Yellowstone Ecosystem (Kay 1990).

After 12 years, the objective of producing more suckers than the elk could suppress was not realized. Initially, enough suckers were produced to reestablish the aspen stands; however, because of heavy utilization most of these suckers have been eliminated or at least severely suppressed. In this situation, fire treatment may have hastened the demise of the decadent aspen. Other prescribed burns in the area were considered successful (Bartos et al. 1991), but they were not subjected to such heavy utilization by elk.

\section{Undergrowth Vegetation}

Annual production of undergrowth vegetation remained relatively constant from 1977 through 1986 (Fig. 1). Proportional differences in total production between the burn severities remained nearly the same over this 9-year period. In 1986, production was approximately $2,190 \mathrm{~kg}$ / ha for high burn severity, $2,140 \mathrm{~kg} / \mathrm{ha}$ for moderate burn severity, and $2,130 \mathrm{~kg}$ / ha for low burn severity. 


\section{Total Undergrowth}

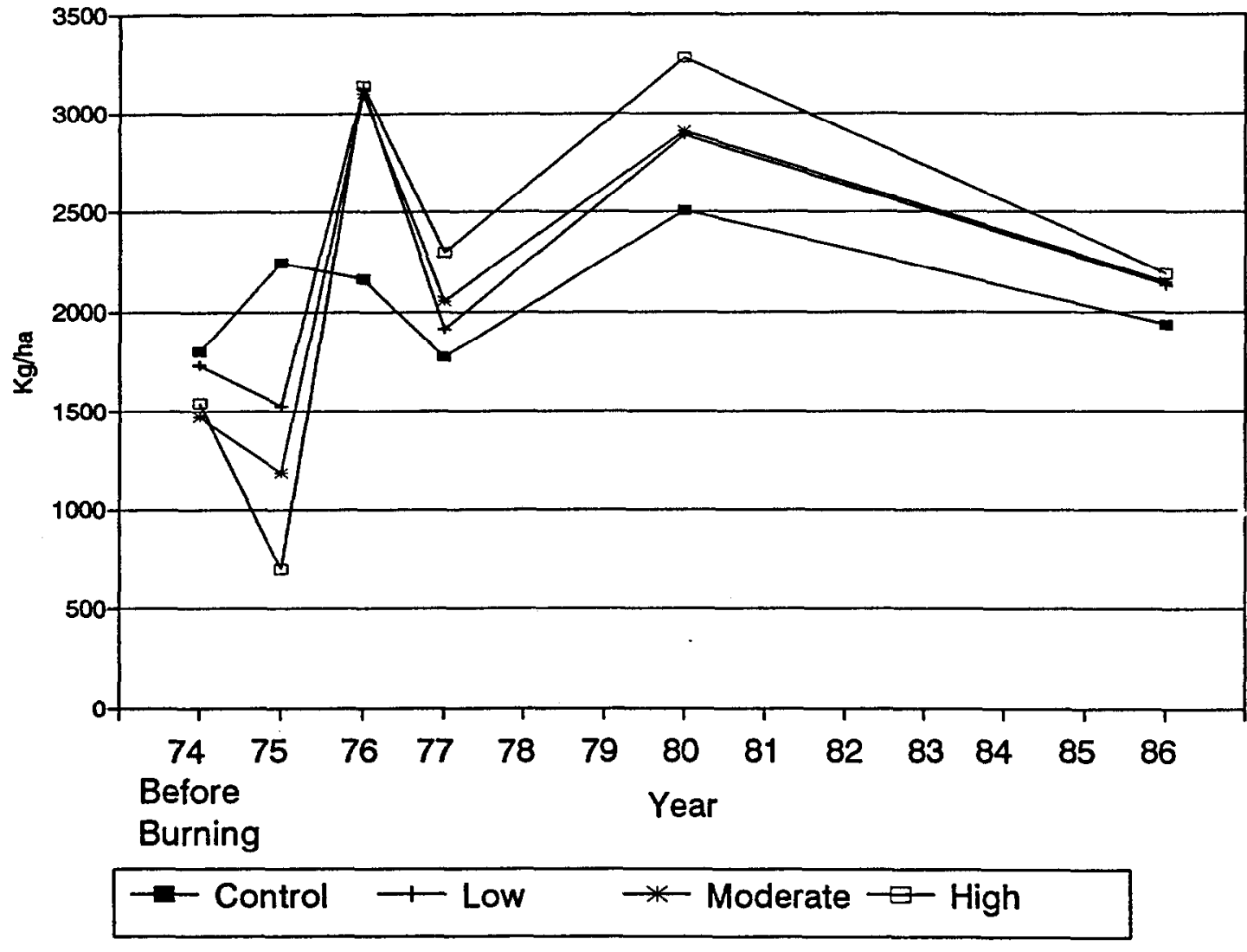

Fig. 1. Total undergrowth production for sampled years during a 12-year time span following burning in 1974 at 3 burn severities.

This exceeded preburn production by 42,46 , and $23 \%$ respectively. Thus, increased production stimulated by burning was still evident 12 years after treatment. However, the differences between preburn and current production had narrowed.

Statistical interaction between burn severity and years for total production was significant $(P=0.0061)$, therefore, evaluations were done on a yearly basis. Total production was found to not be significant between all 3 burn severities and the control site across all years (Table 2). Nonetheless, proportionality of production among burn severities was consistently about the same for the past 10 years (Fig. 1) with that being produced in 1986 being virtually the same for all burn severities. These data show that generally low severity burns were less effective than moderate to high severity burns at stimulating production for long periods.

Forbs dominated the undergrowth composition both before and after burning. Before burning, total production consisted of $66 \%$ forbs, $21 \%$ grasses, and $13 \%$ shrubs. In 1980 , the percentage of total production comprised of forbs on low, moderate, and high severity burns respectively, had increased to 82,84 , and $92 \%$ and then by 1986 dropped to 73, 79, and 73\%. For the 6 years sampled, grasses contributed $20 \%$ or less and shrubs approximately $5 \%$ of the total production on the treated areas. These values were half or less than half of what occurred on the pretreatment site and on the control area. Most of the fluctuation in vegetation composition occurred in the high severity burn. After 12 years, the proportion of total production in forbs was similar to that before fire while it was higher for grasses and lower for shrubs.

Forb production increased dramatically the first 3 years after burning (Bartos \& Mueggler 1981) then decreased gradually dur- ing the following 9 years (Table 2). After 12 years, forb production for the different burn severities was 5 to $14 \%$ greater than estimated prior to burning. An equal amount of forbs was recorded for the control area in 1986. A statistically significant interaction, between burn severity and the number of years after burning, was highly significant $(P=0.0001)$ for forb production, indicating that the forb production growth pattern depended on the severity of the burn. No differences were found in forb production between burn severities and the control area prior to burning in 1974. One year after the fire, forb production was generally less than before fire. There were significantly fewer forbs produced on the moderate and high severities than the control in 1975 (Table 2). However, 2 years following fire, forb production peaked and all 3 burn severities were significantly higher than the control (Table 2). Forb production was more than the control for the next 10 years and was greater on high severity than on low severity burns. Differences between high severities and the control were statistically significant in both 1977 and 1980. In 1986, all 3 burn severities were similar in forb production. However, forb production on both moderate and high severities was significantly more than that on the control.

Initially, major changes were observed in species composition of forbs. Some of these changes were still obvious 12 years after treatment. The greatest increase in biomass was attributable to fireweed (Epilobium angustifolium L.) (Table 3). Prior to burning this forb comprised only $5 \%$ of the total understory production. Three years after fire and even 12 years later it comprised approximately $48 \%$ of the total production. A similarly dramatic increase in forb production due to mountain hollyhock (Iliama rivularis (Dougl.) Greene) was observed in another aspen prescribed burn 
Table 2. Forbs, grasses, shrubs, and total production (dry wt. kg/ha) for 4 burn severities and 6 sample years for the Breakneck Ridge site which was burned in 1974. Mean values are on top and standard errors of the mean (SEM) are shown below.

\begin{tabular}{|c|c|c|c|c|c|c|c|}
\hline om & & 1974 & 1975 & 1976 & 1977 & 1980 & 1986 \\
\hline Forbs & $\begin{array}{c}\text { Control } \\
\text { Low } \\
\text { Moderate } \\
\text { High }\end{array}$ & $\begin{array}{r}1146 \\
69 \\
1088 \\
107 \\
977 \\
120 \\
1061 \\
124\end{array}$ & $\begin{array}{c}1604 \\
131 \\
1255 \\
120 \\
972^{*} \\
176 \\
610^{*} \\
135\end{array}$ & $\begin{array}{c}-(\mathrm{kg} / \mathrm{h} \\
1435 \\
37 \\
2435^{*} \\
203 \\
2389^{*} \\
272 \\
2793^{*} \\
163\end{array}$ & $\begin{array}{r}1220 \\
67 \\
1528 \\
201 \\
1668 \\
164 \\
2101^{*} \\
204\end{array}$ & $\begin{array}{c}1846 \\
137 \\
2354 \\
252 \\
2454 \\
89 \\
3014^{*} \\
193\end{array}$ & $\begin{array}{r}1430 \\
50 \\
1546 \\
61 \\
1699^{*} \\
37 \\
1593^{*} \\
37\end{array}$ \\
\hline rasses & $\begin{array}{c}\text { Control } \\
\text { Low } \\
\text { Moderate } \\
\text { High }\end{array}$ & $\begin{array}{r}451 \\
17 \\
447 \\
86 \\
313 \\
48 \\
226 \\
36\end{array}$ & $\begin{array}{c}376 \\
87 \\
198^{*} \\
36 \\
132^{*} \\
25 \\
46^{*} \\
21\end{array}$ & $\begin{array}{c}468 \\
110 \\
526 \\
94 \\
394 \\
69 \\
148^{*} \\
56\end{array}$ & $\begin{array}{r}189 \\
28 \\
273 \\
56 \\
227 \\
31 \\
82 \\
18\end{array}$ & $\begin{array}{r}270 \\
24 \\
399 \\
106 \\
310 \\
65 \\
151 \\
24\end{array}$ & $\begin{array}{c}291 \\
23 \\
486^{*} \\
42 \\
332 \\
23 \\
482^{*} \\
26\end{array}$ \\
\hline hru & $\begin{array}{c}\text { Control } \\
\text { Low } \\
\text { Moderate } \\
\text { High }\end{array}$ & $\begin{array}{r}199 \\
42 \\
197 \\
45 \\
180 \\
34 \\
249 \\
59\end{array}$ & $\begin{array}{l}266 \\
18 \\
71^{*} \\
29 \\
81^{*} \\
44 \\
41^{*} \\
15\end{array}$ & $\begin{array}{r}256 \\
76 \\
165 \\
46 \\
310 \\
81 \\
197 \\
40 \\
\end{array}$ & $\begin{array}{c}360 \\
113 \\
108^{*} \\
21 \\
158^{*} \\
43 \\
110^{*} \\
32 \\
\end{array}$ & $\begin{array}{c}388 \\
101 \\
130^{*} \\
37 \\
143^{*} \\
35 \\
115^{*} \\
22 \\
\end{array}$ & $\begin{array}{c}215 \\
34 \\
99^{*} \\
16 \\
111^{*} \\
13 \\
111^{*} \\
18 \\
\end{array}$ \\
\hline Total2 & $\begin{array}{c}\text { Control } \\
\text { Low } \\
\text { Moderate } \\
\text { High }\end{array}$ & $\begin{array}{r}1797 \\
64 \\
1731 \\
145 \\
1470 \\
140 \\
1536 \\
107\end{array}$ & $\begin{array}{r}2246 \\
210 \\
1524 \\
138 \\
1185 \\
223 \\
697 \\
161\end{array}$ & $\begin{array}{r}2160 \\
72 \\
3126 \\
191 \\
3094 \\
314 \\
3139 \\
139\end{array}$ & $\begin{array}{r}1769 \\
159 \\
1909 \\
225 \\
2053 \\
194 \\
2294 \\
215\end{array}$ & $\begin{array}{r}2504 \\
63 \\
6883 \\
182 \\
2907 \\
82 \\
82 \\
3281 \\
170\end{array}$ & $\begin{array}{r}1936 \\
68 \\
2130 \\
74 \\
2141 \\
42 \\
2186 \\
45\end{array}$ \\
\hline
\end{tabular}

'Burn severity means within the same community component in the same column followed by an * are significantly different $(P<0.01$, Dunnett) from the control.

${ }_{2}$ Total production was calculated by summing forbs, grasses, and shrubs.

(Brown and DeByle 1989). Aggressive "pioneer" forb species that dominate undergrowth vegetation during early postfire succession appears to be common in the aspen forest.

An annual, lambsquarter (Chenopodium fremontii Wats.), was evident on the burned plots for the first 3 years (Bartos and Mueggler 1981), but it had disappeared after 12 years. A few forb species on site were not markedly changed by burning. Production of columbine (Aquilegia coerulea James), locoweed (Astragalus miser Dougl.), strawberry (Fragaria vesca L.), northern bedstraw (Galium boreale L.), lupine (Lupinus spp. L.), and fendler meadowrue (Thalictrum fendleri Engelm.), however, has not returned to their preburn levels (Table 3).

Like other species groups, grass production was initially reduced by burning (Table 2). Grasses then increased moderately over the next 11 years. An exception was a 4-fold increase in slender wheatgrass (Agropyron trachycaulum (Livk) Malte) production on the high severity burns in 1986. Analysis of grass production resulted in a statistically significant interaction $(P=0.0323)$ between burn severity and years. In 1975, all 3 burn severities were statistically different from the control. Thereafter, only grass production on the high severity burn different significantly from the control in 1976 and 1986 . Unlike forb production, high severity burns apparently were less favorable for grass production than moderate and light severity burns during the early years following burning. However, Brown and DeByle (1989) observed that rhizomatous grasses
Table 3. Production (air-dry $\mathrm{kg} / \mathrm{ha}$ ) of major undergrowth species before burning (1974) and on the light, moderately, and heavily burned plots 12 years following burning (1986).

\begin{tabular}{|c|c|c|c|c|}
\hline & \multirow[b]{2}{*}{$\begin{array}{l}\text { Before } \\
\text { burning }\end{array}$} & \multicolumn{3}{|c|}{ After burning } \\
\hline & & \multicolumn{3}{|c|}{ (Burn severity) } \\
\hline & \multirow{2}{*}{\multicolumn{4}{|c|}{$\ldots \ldots(\mathrm{kg} / \mathrm{ha}) \ldots \ldots \ldots$}} \\
\hline Forbs & & & & \\
\hline $\begin{array}{l}\text { Achillea lanulosa (nutt.) } \\
\text { Piper }\end{array}$ & 14 & 12 & 17 & 12 \\
\hline Aquilegia coerulea James & 56 & 8 & 33 & 4 \\
\hline Astragalus miser Dougl. & 46 & 6 & 10 & 11 \\
\hline $\begin{array}{l}\text { Chenopodium fremontii } \\
\text { Wats. }\end{array}$ & 0 & 0 & 0 & 0 \\
\hline Epilobium angustifolium $\mathrm{L}$. & 68 & 970 & 1067 & 1114 \\
\hline Fragaria vesca $\mathrm{L}$. & 108 & 75 & 14 & 45 \\
\hline Galium boreale $\mathrm{L}$. & 33 & 13 & 14 & 15 \\
\hline $\begin{array}{l}\text { Geranium viscosissimum } \\
\text { F. \& M. }\end{array}$ & 297 & 125 & 359 & 223 \\
\hline Lupinus spp. $\mathbf{L}$. & 221 & 160 & 124 & 94 \\
\hline Potentilla gracilis Dougl. & 43 & 60 & 0 & 0 \\
\hline Thalictrum fendleri Engelm. & 62 & 48 & 40 & 34 \\
\hline Valeriana occidentalis Heller & 3 & 13 & 21 & 0 \\
\hline \multicolumn{5}{|l|}{ Grasses } \\
\hline $\begin{array}{l}\text { Agropyron trachycaulum (Link) } \\
\text { Malte }\end{array}$ & 49 & 53 & 51 & 259 \\
\hline $\begin{array}{l}\text { Bromus ciliatus L. } \\
\text { Poa spp. L. }\end{array}$ & $\begin{array}{r}217 \\
41\end{array}$ & $\begin{array}{r}290 \\
66\end{array}$ & $\begin{array}{c}291 \\
47\end{array}$ & $\begin{array}{c}256 \\
61\end{array}$ \\
\hline \multicolumn{5}{|l|}{ Shrubs } \\
\hline Populus tremuloides Michx. ${ }^{1}$ & 27 & 26 & 28 & 15 \\
\hline Rosa woodsii Lindl. & 53 & 34 & 85 & 51 \\
\hline $\begin{array}{l}\text { Symphoricarpos oreophilus } \\
\text { Gray }\end{array}$ & 88 & 48 & 25 & 18 \\
\hline
\end{tabular}

${ }^{1}$ Limited to aspen suckers which are defined as a single reproductive unit less than 2-m tall and less than 5-cm diameter at breast height (dbh).

such as pinegrass (Calamagrostis rubescens Buckl.), which did not occur on Breakneck Ridge, can increase substantially on moderate and high severity burns. The increased grass production on Breakneck Ridge during 1986 was due to equal amounts of slender wheatgrass and fringed brome (Bromus ciliatus L.) (Table 3). These species produced biomass on the low and moderate severity burns comparable to preburn production.

The exceptional increased production of grass on high severity burns in 1986 leaves uncertain the effect of burn severity on grass production. It appears that slender wheatgrass was stimulated by the high severity burn. During the study, Breakneck Ridge was subjected to livestock grazing 3 out of 4 years in a rest rotation system. It should be noted, however, that no livestock grazing was evident prior to sampling in 1986. Grazing pressure prior to 1986 on the system may have distorted observed vegetation production, especially the grass category.

Shrubs were harmed by burning and did not regain preburn production levels even after 12 years (Table 2). For shrubs, interaction between burn severity and years was not statistically significant $(P=0.9212)$. This statistic implies pooling across all years is in order; however, we chose to look at individual years to maintain consistency with the other analysis. Differences in production between all burn severities and the control were significant for all years except 1974 and 1976 (Table 2). After 12 years, snowberry (Symphoricarpos oreophilus Gray) (Table 3) was still producing about half of that being produced prior to treatment. Both wildrose (Rosa woodsii Lindl.) and aspen suckers were producing about the same as preburn. Brown and DeByle (1989) observed varied recovery rates of shrub biomass 5 years after fire. Preburn composition, fire damage to perenniating parts, use by ungulates, 
and postburn competition could all influence shrub recovery.

\section{Summary and Conclusion}

Initially, enough aspen suckers (app. 20,000 suckers/ha) were produced as a result of burning aspen stands on Breakneck Ridge to regenerate the deteriorating aspen clones. Twelve years later there was a tenth of that number of suckers, and with only an average height of $.5 \mathrm{~m}$. Suppression of the suckers is attributed mainly to heavy use by elk. We question the continued use of fire to regenerate aspen stands that are subjected to heavy ungulate use. Such action could speed the elimination of aspen stands under these conditions.

We found that even 12 years after fire production of forbs, grasses, and the total undergrowth was greater than before fire. Production of forbs and grasses decreased the first year after fire, then increased and remained above preburn levels. However, increased production the first year following fire is also possible in aspen forests (Brown and DeByle 1989). Recovery of shrubs was slow, perhaps because of competition from herbaceous vegetation and use by ungulates.

Moderate and high severity burns produced the most undergrowth because of aggressive recovery of forbs. At Breakneck Ridge, the forbs appeared better able to survive high severity fires than the grasses because their regenerative mechanisms are better protected from heat injury. However, early successional patterns following fire depend on preburn species composition and competitive abilities as well as burn severity. Thus, varied responses to fire can be expected. Production and composition appear to be slowly returning toward preburn conditions.

\section{Literature Cited}

Baker, F.S. 1925. Aspen in the central Rocky Mountain Region. USDA Agr. Bull. 1291

Bartos, D.L. 1979. Effects of burning on the aspen ecosystem. In: Proc. Eighth Wyoming Shrub Ecolgy Workshop, Jackson, Wyo. p. 47-58.

Bartos, D.L., and W.F. Mueggler. 1979. Influence of fire on vegetation production in the aspen ecosystem in western Wyoming. In: Boyce, M.S., and L.D. Hayden-Wing (eds) North American Elk Ecology, Behavior and Management, Univ. of Wyoming, Laramie. p. 75-78.
Bartos, D.L., and W.F. Mueggler. 1981. Early succession in aspen communities following fire in western Wyoming. J. Range Manage. 34:315-318.

Bartos, D.L., W.F. Mueggler, and R.B. Campbell, Jr. 1991. Regeneration of aspen by suckering on burned sites in western Wyoming. USDA Forest Serv. Res. Pap. INT-448.

Brown, J.K., and N.V. DeByle. 1987. Fire damage, mortality, and suckering in aspen. Can. J. For. Res. 17:1100-1109.

Brown, J.K., and N.V. DeByle. 1989. Effects of prescribed fire on biomass and plant succession in western aspen. USDA Forest Serv. Res. Pap. INT 412.

Currie, P.O., M.J. Morris, and D.L. Neal. 1973. Use and capabilities of electronic capacitance instruments for estimating standing herbage. Part 2. Sown ranges. J. Brit. Grassl. Soc. 28:155-160.

DeByle, N.V., and R.P. Winour. (eds.) 1985. Aspen: ecology and management in the western United States. USDA Forest Serv. Gen. Tech. Rep. RM-119.

Despain, D., D. Houston, M. Meagher, and P. Schullery. 1986. Wildlife in transition: man and nature on Yellowstone's northern range. Roberts Rinehart Inc., Boulder, Colo.

Dunnett, C.W. 1955. A multiple comparison procedure for comparing several treatments with a control. J. of the Amer. Stat. Assoc. 50:1096-1121.

Gruell, C.E., and L.L. Loope. 1974. Relationship among aspen, fire, and ungulate browsing in Jackson Hole, Wyoming. U.S. Forest Serv., Intermountain Region, Ogden, Ut.

Houston, D.G. 1982. The northern Yellowstone elk: ecology and management. Macmillan Publ., N.Y.

Jones, J.R., and N.V. DeByle. 1985. Fire, p. 77-81. In: DeByle, N.V., and R.P. Winokur, (eds). Aspen: Ecology and management in the western United States. USDA Forest Serv. Gen. Tech. Rep. RM-119.

Kay, C.E. 1990 . Yellowstone's northern elk herd: a critical evaluation of the "natural regulation" paradigm. Ph.D. Diss. Utah State Univ., Logan.

Mueggler, W.F. 1989. Age distribution and reproduction of Intermountain aspen stands. West. J. Appl. Forest. 4:41-45.

Mueggler, W.F., and D.L. Bartos. 1977. The grindstone flat and big flat exclosures - a 41-year record of changes in clearcut aspen communities. USDA Forest Serv. Res. Pap. INT-195, 16 p. Intermt. Forest and Range Exp. Sta., Ogden, Ut.

Patton, D.R., and H.D. A vant. 1970. Fire stimulated aspen sprouting in a spruce-fire forest in New Mexico. USDA Forest Serv. Res. Note RM-159.

Ryan, K.C., and N.V. Noste. 1985. Evaluating prescribed fires, p. 230-238. In: Lotan, J.E., B.M. Kilgore, W.C. Fischer, and R.C. Mutch, (tech. coords). Proc. Symposium and Workshop on Wilderness Fires. USDA Forest Serv. Gen. Tech. Rep. INT-182.

Schier, G.A., W.D. Sheppard, and J.R. Jones. 1985. Regeneration, p. 197-208. In: DeByle, N.V., and R.P. Winokur, (eds). Aspen: Ecology and management in the western United States. USDA Forest Serv. Gen. Tech. Rep. RM-119. 